慶應義塾大学学術情報リポジトリ

Keio Associated Repository of Academic resouces

\begin{tabular}{|c|l|}
\hline Title & Characterization of Structures with T-Lymphocyte Aggregates in Ileal Villi of Crohn's Disease. \\
\hline Sub Title & クローン病回腸絨毛内におけるT-リンパ球の集簇 \\
\hline Author & 長沼, 誠(Naganuma, Makoto) \\
\hline Publisher & 慶應医学会 \\
\hline Publication year & 2003 \\
\hline Jtitle & 慶應医学 (Journal of the Keio Medical Society). Vol.80, No.1 (2003. 3),p.17- \\
\hline JaLC DOI & \\
\hline Abstract & \\
\hline Notes & 号外 \\
\hline Genre & Journal Article \\
\hline URL & $\begin{array}{l}\text { https://koara.lib.keio.ac.jp/xoonips/modules/xoonips/detail.php?koara_id=AN00069296-2003030 } \\
4-0017\end{array}$ \\
\hline
\end{tabular}

慶應義塾大学学術情報リポジトリ(KOARA)に掲載されているコンテンッの著作権は、それぞれの著作者、学会または出版社/発行者に帰属し、その権利は著作権法によって 保護されています。引用にあたっては、著作権法を遵守してご利用ください。

The copyrights of content available on the KeiO Associated Repository of Academic resources (KOARA) belong to the respective authors, academic societies, or publishers/issuers, and these rights are protected by the Japanese Copyright Act. When quoting the content, please follow the Japanese copyright act. 


\title{
Characterization of Structures with T-Lymphocyte Aggregates in Ileal Villi of Crohn's Disease.

\author{
（クローン病回物峨毛内におけるT-リンパ球の集簇）
}

\author{
長 沼誠
}

\section{内容の要旨}

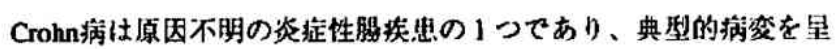
さない场合には沴断に﨎涉することが多い。特にCrohn病の訩断基染

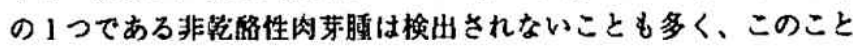

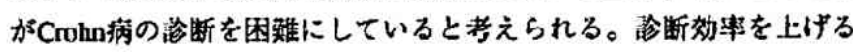
ため、これまでに内梘镜学的・病理学的研究が行われてきているが、 Crohn病の好発部位である回脂粘膜についての研究は少ない。

本研究において、著者はCrohn病の回照粘䐅絾毛内にリンバ球集旅 が存在することを見いだした。本研究では、まず回晹䋐毛内リンパ 球集旅がCrohn病に特哄的な所見であるかについて検討した。32例の Crohn病出者の回䐎粘膜を手衍時・内視镜生换時に探取し、リンバ球 集族の有無の㛟樂をおこなった。その耛果手衍検体18例中14例、内

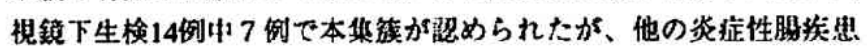

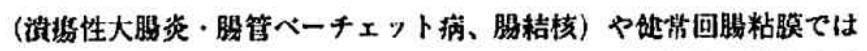

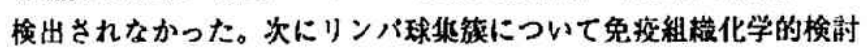

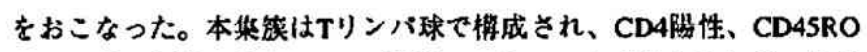

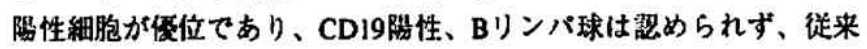
のリンバ㵂胞やバイエル板のリンバ球のphenotypeとは異なってい た。また集筷内にCD68陆性のマクロファージが毁められ、その一部 でCrohn病の病热形成に重要なサイトカインであると考えられている

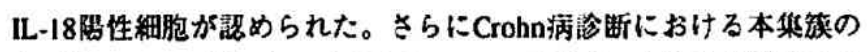
有用性について狛らかにするため、Crohn病惢者における回晹絨毛内

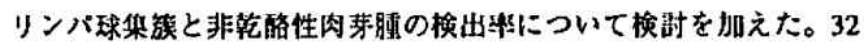

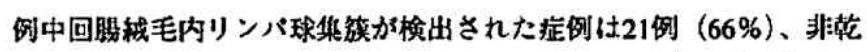

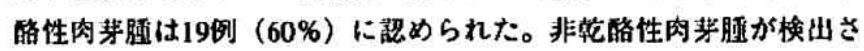

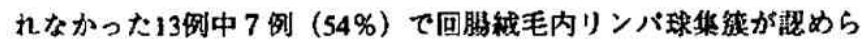

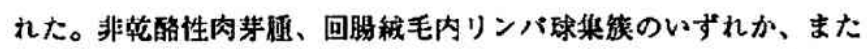
は西方検山された亚例は32例中26例、81\%と高化であった。また回

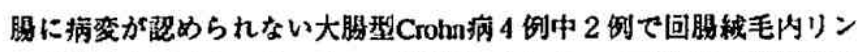
バ球集族が鼣められたことや、回晹䄉毛内リンバ球集族陆性例と陰

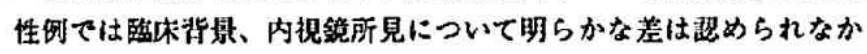
ったことより、絬膜の炎症の程度や病気の活功性とは阅係なく本集 族が琶められる可能性があると考えられた。

以上より回腸被毛内リンバ球集皦はCrohn病の病腎形成に重要な意

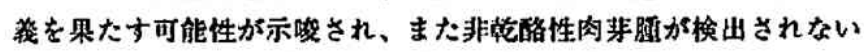
埾合のCrohn病の褀助瞈断として有用であることが示された。

\section{論文蜜㭗の要旨}

非乾酪性肉芽䏦はCrohn病における病理学的特徽の1つであるが、

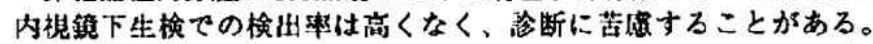

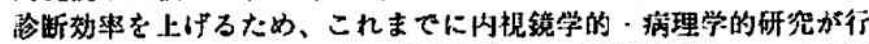
われてきているが、Crohn病の好発部位である回脂粘槚についての研 究は少ない。

中請者はマウス1ELのprogenitorであるcryptopatchがヒト胉管粘膜に 存在するかについて追求する递程で、Crohn病の回晹粘脱絨毛队にリ ンバ球集䈘が存在することを見いだし、このリンバ球がCD3隄性T細 胞であることより、T lymphocyle aggregate (TLA) と名づけた。本 研究ではTLAについて兔将組杫化学的検討をおうない、さらにCrohn 病浐断に対するTLAの有成珄について検时を加之た。その結果、京 定したTLAのリンパ球がCD4隄性細胞であり、CD68・IL-18隄性マク ロフrージが翟められたことより、TLAはCrohn病の病隹形成に重荘 な意媵を果たす叮能性が示咬され、さらに病気の活趿性と咸俰なく

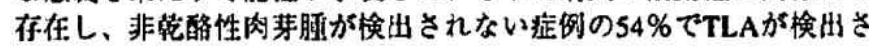

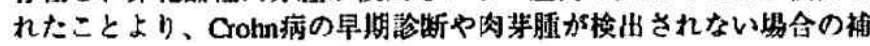
助浴断としてTLAが有用であることを示した。

海査ではまず本研究がcryptopatchに端を吿した研究であるにもか かわらす、決䛺文のintroductionで言及されていないとの指摘があっ

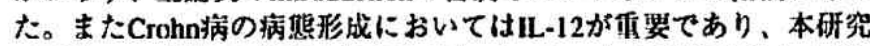
では抗IL-12抗体の免疫染色がなされていないとの指墒がされたが、 サイトカインの免疫染色は困萑な場合が多く、良好な秙果が得られ なかったと回签された。次にTLAのCrohn病病䈍への成与についての

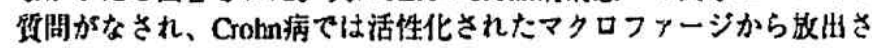
れるIL-12により、ヘルパーT練胞（Th0）がTh|練胞となり、これよ り故出される炎症性サイトカインが病態に閉係するが、この過程で

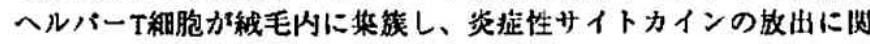
与する可能性があると回答された。さらにTLAについての病理学的

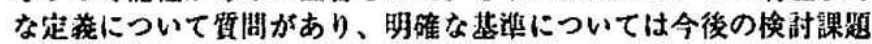

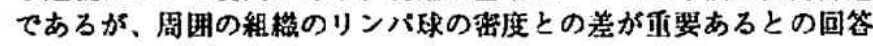
がされた。またTLAをCrohn病の診断基淮とするには、他の炎往性䏸 疮患を含めて检时数が少ないことが指摘されたが、患者数が少ない

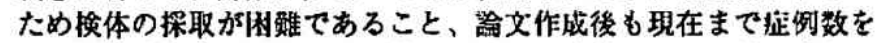
俤やして検討しているとの回答がされた。设後にアフタ性陆资から Crohn满に進展した症例でTLAがアフタ性隄炎の段倩で粀断に結びつ

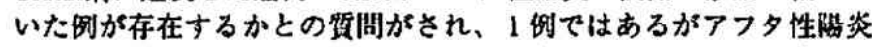

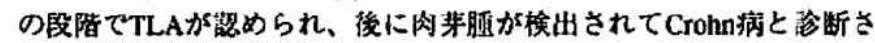
れた症例があると回答された。

以上本研究ではなお検洷すへき点が残るものの、TLAがCmhn病䛌 断に有用であること、およびCrohn病の病熊形成に种要な意義を果た

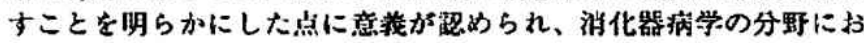
いて価値のある研究であると呼価された。

\begin{tabular}{|c|c|c|c|c|c|}
\hline 誦文哖查担当者 & 主查 & 内科学 & 石井 & 铂正 & \\
\hline 外科学 & 北岛 & 政掊 & 病理学 & 風田 & 保典 \\
\hline 病理学 & 坂元 & 孛宇 & 俶生物学 & 小安 & 重夫 \\
\hline 了確现把当者 & ：北岛 & 政樹 & & & \\
\hline 篓查委只 & - 北幽 & 政樹 & & & \\
\hline
\end{tabular}

試間日：平成14年12月24日 